\title{
"Liegst dem Erdteil Du inmitten, einem starken Herzen gleich": How Central and/or European is Austria's Cultural Identity?
}

CORNELIA SZABÓ-KNOTIK

When Austria wanted to become a member of the EU, which it successfully did in 1995, the government's public relations efforts explicitly involved Austrian identity markers. Discussions centered on two main markers - food and culture -, and while the former seem to have needed support against the dangers of the common market (the protection of certain brands like Wachauer Marillenmarmelade and Steirisches Kernöl was made a precondition of the membership agreement), the latter seems to have remained unquestioned.

Ten years later, the celebrations of this membership's anniversary coincide with a special occasion: for the first half of 2006, Austria holds the presidency of the EU council. Both the anniversary and the presidency are incentives to promote the country's position within the EU, especially as the Austrian public seems to be more critical of this membership than a decade ago. The structure of and arguments for this promotion provide a framework to reflect on the cultural markers used in the construction of Austrian identity. The amount of possibly useful materials for such a study being rather overwhelming, I decided to focus on the official promotion materials, mostly publications listing the packed program of activities and a number of (more or less) official statements (if no other source is given, those were accessed through www.oesterreich2005.at or the www.bmaa.gv.at website). These form the basis of the analysis of current images of Austria's cultural identity that follows.

At the same time I started work on these materials, I came across a piece of news that proved useful in determining my approach. It was about the so-called "Austrian State Prize for European Literature" 
(Österreichischer Staatspreis für europäische Literatur), "European Literary Award" (Europäischer Literaturpreis) for short - an award which has existed since 1965 and has featured Simone de Beauvoir, Friedrich Dürrenmatt, Umberto Eco as awardees. In 2005, the prize was conferred to Julian Barnes. At the award presentation, which took place on 9 August 2005, in Salzburg, i.e. during the Salzburg Festival, Barnes did two things I found most remarkable: he claimed in his speech that "the European is the local"; and he asked that members of the Vienna Philharmonic play string quartet pieces by Joseph Haydn. For me as a music historian, this combination of a pointed remark about the tensions between the regional and the European (a variant of "the global is the local") with a very traditional notion of classical art music (a style for which Haydn is one of the founding fathers and the string quartet one of the central musical genres) as a universally valid style, a "language the whole world understands" (as a saying has it that is anecdotally attributed to Haydn himself), raised the question of whether traditional patterns of Austrian identity are currently undergoing a process of modification. When the Director of the Vienna Burgtheater, Klaus Bachler, stated in his speech at the celebrations of the $50^{\text {th }}$ anniversary of that building's re-opening on 14 October 2005 that "the national air [gestus] characteristic of the celebrations in 1955 should today give way to a European awareness" - note that he said should, not did! - I felt confirmed in my approach. I therefore begin the following analysis by considering how, and to which degree, this European awareness actually does constitute a part of the Austrian self-description and, in doing so, draw on the notion of a special relation to music. I will include some background on twentieth-century traditions to describe the relation of Austrian identity to its European situation in specific political and cultural contexts.

A) AUSTRIA'S WAYTO EUROPE - TRADITIONS

When, as a consequence of Austria's application for full membership in the European Union, a commission had to examine the candidate's European identity, it stated:

The Union will profit from the experiences of a country that is - because of its geographical position, its past and its inherited and newly gained relations situated precisely in the center of activities from which the new Europe will be built. (Breuss et al 127) 
This statement clearly alludes to the country's Central European experiences. On the one hand, it mentions the Monarchy ("its inherited position"); on the other hand, the events after the so-called fall of the iron curtain in 1989 ("its newly gained relations"). Such a positioning of Austria in the "heart of Europe" corresponds to a longstanding selfdescription dating from the years of the First Republic and relying on its monarchical past. A text still frequently quoted was formulated by Hugo von Hofmannsthal, who until his suicide closely cooperated with Richard Strauss and wrote the librettos for six of his operas - from Electra (1909) and Rosenkavalier (1911) to Arabella (1929) - and who was one of the "inventors" of the idea of the Salzburg Festival (his Jedermann (1911) remains a ritualized part of the festival). At the demise of the Habsburg Empire in 1917, he equated Austria with the "idea of Europe":

Naming Austria means naming 1000 years of battling for Europe, 1000 years of calling for Europe, 1000 years of believing in Europe. (Breuss etc. 127)

After 1945, the image of Austria as a "mediator between the blocks" was of fundamental importance for its foreign policy, and, since the mid1980s, visions of a common Central European region have been revitalized and Central Europe defined as the "Danube region" (DonauRaum). This construction has historical and mental dimensions, first of all for the intellectuals in the respective countries and, as a result, for Austrian politicians. The Austrian application for EU membership in 1989 bridged the Central European focus with EU interests. Foreign policy during these years meant "neighbor policy," to which also the activities during the conflicts following the break-up of Yugoslavia in the early 1990s have to be attributed.

Eventually these political visions of Central Europe were relinquished and subordinated to EU policy. In 1994 a large-scale campaign during the run-up to the referendum on membership tried to establish a "European identity" in Austria. The slogan "we are Europe" identified Europe with the EU. The government strove at this point to be a driving force in the EU integration project. As European parliament deputy Ursula Stenzel from the Austrian People's Party (ÖVP) stated in 1998: "The enlargement is useful for us as it moves Austria again into the heart of Europe" (Frölich-Steffen 207). On the national holiday (26 October) in 2000, President Thomas Klestil stated: "The enlargement offers a unique opportunity to build a zone of peace and prosperity through cooperation as equal partners with our neighbors - and this in 
the interest of all of Europe" (Frölich-Steffen 208). His image of Austria as a peace-bringing country is also a traditional pattern of its identity construction and promptly (re-)appears in current story-telling on how joining the EU was managed. During the late 1990s Austria's engagement with Central Europe took the form of cultural activities, the keyword being the "Austrian cultural bridge-building policy." This definition is obviously still relevant. The guidelines for Austrian foreign cultural policy (Auslandskulturpolitik - a wonderful option for scrabbleplayers) in the form currently accessible on the Ministry's website explicitly state that this is one of the country's "great cultural achievements," a world-wide perception supposedly advantageous in the "competition for attention." And alluding to Stefan Zweig, who is said to have proclaimed that he loved Austria because it allowed him to be a patriot and a cosmopolitan at the same time (a phrase that can be found in an article on the relation of patriotism and cosmopolitanism by the enlightened author Christoph Martin Wieland), the head of the Foreign Ministry's Department for Cultural Politics, Emil Brix, stresses the importance of engaging in "a Europe of diversity" instead of national relations in order to counteract "an excessive amount of identity politics."

Foreign policy seen as being based on "cultural bridge-building" is well rooted in the definition of Austria as a so-called Kulturnation (nation of culture), the characteristics of and arguments for which can also be traced back to the final years of the Habsburg monarchy. From this time through the years of the First Republic, of Austro-Fascism and of National Socialism up to the Second Republic, public as well as private opinion in Austria maintained the notion of a country characterized by its high standards of culture in general and music in particular (both as a paradigm and as a practice). This high standard is said to have been achieved by a population with a, as it were, "natural" inclination and talent for the arts, providing both excellence in production as well as the singularity of expertise (Frölich-Steffen quotes a 1999 opinion poll which finds that in comparison to other countries, the share of leisure musicians and artists is remarkably high in Austria: about $25 \%$ of its population play an instrument, $31 \%$ pursue other artistic activities (242)). This is epitomized in the clichéd terms Musikland (nation of music) and Musikstadt, referring to Vienna (cf. Nußbaumer, Szabó-Knotik). Austrian politicians throughout the twentieth century have time and again stressed these topics whenever it was necessary to compensate for economic weaknesses or ideological 
deficits. "Culture" has been the main focus of all strategies for marketing the country's image since tourism became a main source of income in the 1950s.

Since its beginnings, one component of this Musikland topos has been particularly relevant for matters of the country's European identity: the customary reference to Austria's geographical position at the crossroads of cultures and traditions. In the context of the Musikland construction, this reference provides an argument for its quasi-natural role as a mediator in this area - a role that is, for its part, supported by the positive qualities the bourgeois view traditionally ascribes to music (Romantic aesthetics), and a role that was referred to all too soon when, after the end of WWI and WWII, it became advantageous to let Austria's part in the respective conflicts slide into oblivion, for reasons easy to guess.

Regarding this tradition and its successful application, it is no surprise that the same line of argumentation was readily adopted to promote Austria's negotiations with the European Union. When the 1994 referendum eventually resulted in considerable acceptance, paving the way for membership, it was again culture that politicians used as one of Austria's defining features. Creative artists were regarded as the country's ambassadors and, together with politicians, strove to position Austria as the Union's cultural and intellectual center (Frölich-Steffen 244). This process has also influenced foreign affairs. When in 1989 Austria, Hungary, Italy, Yugoslavia, Czechoslovakia and Poland joined the so-called Hexagonale, which, after the disintegration of Yugoslavia, was renamed the Central European Initiative (CEI) and currently includes no fewer than 17 states in Central and Eastern Europe, the scope of their activities was a broad range of exchange, with culture being just one element. But when in June 2001 a basis for regional cooperation called Plattform Kultur Mitteleuropa was established, which included Poland, the Czech Republic, Slovakia, Slovenia and Austria, culture was, as one could guess from the name, the group's chief concern (www.bmsg.gv.at/cms/site/detail.htm? channel=CH0248\&doc=CMS11 25474620747; www.idm.at/veranstaltungen/Kreid.doc)

Having reviewed the traditional elements of the country's political development and its cultural identity, we can now move on to current constructions of the "how we joined the Union" story and related cultural activities and explain how Austria's European self-awareness is being signified. 
B) AUSTRIA'S EUROPEAN WAY - A RECENT SNAPSHOT

Commemorations are always an occasion for focusing on history and for constructing narratives that establish and confirm significations. Therefore, it is a first point of interest for this "snapshot" of the current state of Austria's cultural identity constructions to reflect on public storytelling, i.e. public references to "how EU membership was achieved" and to note the role played by possible clichéd images in this process.

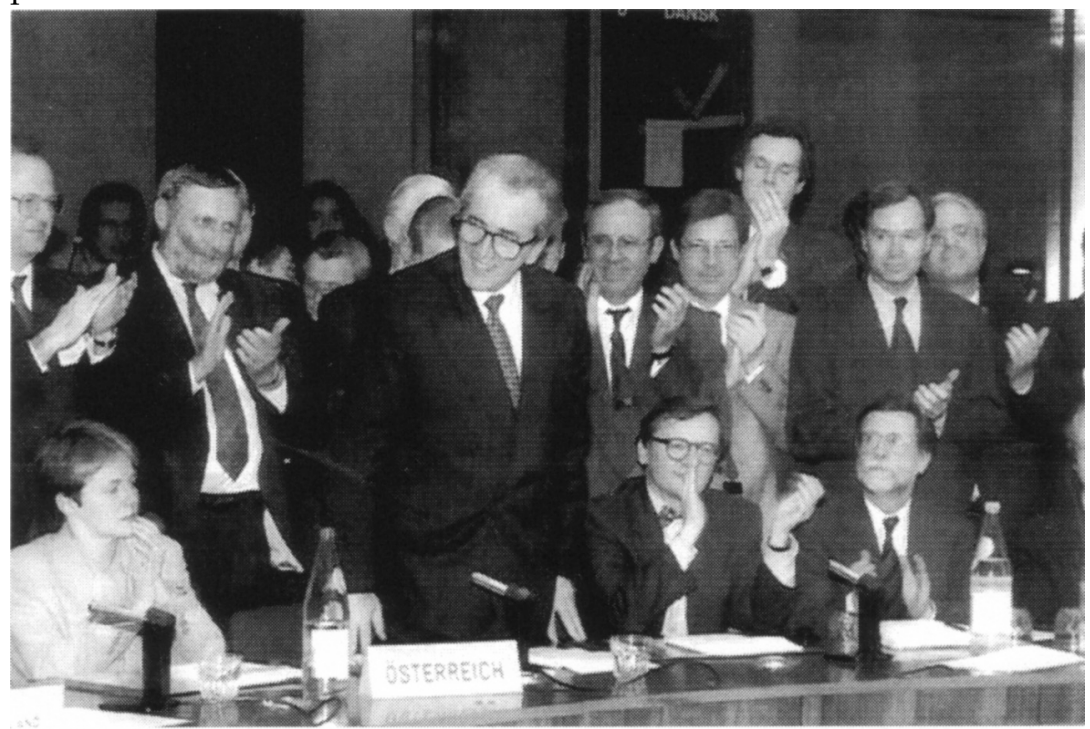

Einigung über die Bedingungen des EU-Beitritts am 1. März 1994 in Brüssel: Außenminister Alois Mock (Mitte) mit EuropaStoatssekretärin Brigitte Ederer, Wirtschaftsminister Wolfgang Schüssel, Botschafter Manfred Scheich (v.l.n.r.). Hinter Mock Landwirtschaftsminister Franz Fischler (der spätere EU-Kommissar) sowie Johann Farnleitner (stellvertretender

Generalsekretär der Österreichischen Wirtschaftskammer). (Foto: apa)

Illustration 1

A very characteristic document and one easily accessible as it is published on the web is the speech Martin Purtscher, former provincial governor of Vorarlberg, gave on the occasion of the Vorarlberg provincial government's so-called Europatag (day of Europe) on 9 May 2005 (www.vorarlberg.at/pdf/alt-lhdr_martinpurtscher-.pdf).

Austria's "path to Europe" in Purtscher's version is primarily a 640 year-old tradition of European influence, obliterated in 1918 by the dissolution of the Monarchy, "frequently seen in the past as well as in the present as the EU's predecessor," and re-established "albeit under completely different circumstances" in 1995: "As a small nation, we had since then been of the same size, but in the European Union we gained an 
over-proportional right to share in the decision-making." In order to link the old imperial tradition as closely and as immediately as possible to recent developments, Purtscher has to disregard the years between WWI and 1995, years characterized by considerable political changes (to put it mildly), and he does so with the remarkable statement that:

1918 was followed by 77 years of international insignificance. During seven of those years, even the name Austria disappeared when our country was degraded to being the Ostmark.

Purtscher's description culminates in the moment after the signing of the treaties, marked by a phraseology filled with pathos, the message of which is to praise Austrian patriotism as transcending all political conflicts:

The Greek chair congratulated first in contemporary Greek, then he switched into ancient Greek to mark the moment's importance - nobody understood, there was no interpreter - and then [Austrian Foreign Minister] Mock responded, and it was his speech that I could never, ever forget. Putting his manuscript aside, he first thanked everybody for their patience, but then he sang such a praise of Austria, of "what Austria contributes to the EU on the basis of its history, above all its cultural history," that we all had tears in our eyes, in any case the Austrian delegates - we were not ashamed of our tears [...] And we were told that nothing similar had ever happened. There was no representation of particular parties or interests any longer, we were all Austrians. This was an incredibly strong feeling. And I believe that it was only because of this that finally the breakthrough had been achieved.

First, this passage echoes two texts traditionally used as lieux de mémoire for Austrianness, namely Anton Wildgans's Speech on Austria (from 1929, written with the aim of promoting Austria in Sweden) and Ottokar's "Praise of Austria" from the third act of Franz Grillparzer's King Ottokar, His Rise and Fall, which was performed at the re-opening of the Burgtheater in 1950 and also premiered at this year's corresponding celebrations at the Salzburg Festival in a modernist staging (showing, for example, Ottokar's counterpart Rudolf as a populist politician distributing wiener schnitzel to the people). It is worth mentioning that the same Martin Purtscher calls Alois Mock, in a letter congratulating him for his 70th birthday, the "hero of Brussels" and directly refers to Grillparzer's text: "His praise of Austria reminds me of Grillparzer's praise [...] (www.alois-mock.at/leben/artikelasp?where=009811).

Secondly, the passage recalls one of the Second Republic's founding myths, namely the common experience of persecution that had made it possible to bridge the political conflicts between conservatives and social democrats, conflicts that had contributed to the destruction of the 
First Republic (the spirit of opposing "camps"). Purtscher accounts for the high percentage of skepticism (keyword: Euro-barometer) with the fact that the EU has widely forgotten the most important motive for its foundation, namely peacekeeping. He mentions the Helsinki charter, the participation in UN-peacekeeping missions and Bertha von Suttner (whose 100-year anniversary was also celebrated in 2005) in order to stress Austria's qualifications in this field. And he alludes to culture as the principal contribution Austria has to make to the EU, defining the values of European culture with a set taken from traditional education as represented by Greek philosophy, Roman law, Christian ethos and the values of the Enlightenment: "Basically the European community is above all a community of values and culture."

Purtscher's narrative is clearly influenced by a politically conservative tradition, but this is nothing personal and is not limited to people of his generation (he was born in 1928), who were educated during the period of Austro-fascism and shaped by the experience of the Third Reich and Austria's so-called "reconstruction" afterwards. This tradition is the one currently being mobilized for the construction of Austria's European awareness, something that can be demonstrated by comparing his narrative with the theme of the official cultural activities on the above-mentioned Ministry of Foreign Affair's website. Supposedly quoting Camus (quotes from world literature seem to demonstrate erudition as part of a slowly fading tradition of Austrian conservative politicians), Emil Brix states that Europe is to be regarded as a common cultural project, and that Austria has joined the EU on the basis of this conviction. Being a Kulturnation and relying on culture as its - literally (Brix uses the English expression) - "unique selling point," Austria is said to have always as a matter of course integrated "the other" because culture creates identity and relations. It was, therefore, Austria's aim to participate in fully integrating southeastern Europe into the European cultural dialogue, stabilizing these countries by strengthening their "civil societies." The precondition for this task is seen in the fact that "during our history we have had experience with the conflict of languages and cultures as well as with totalitarian ideologies" - a notion that expresses the same view as Martin Purtscher: of the Monarchy as a predecessor of the EU and of Austria as a victim of National Socialism. The enlargement of the European Union - and this is another point alluded to in Purtscher's but also in Franz Fischler's speech on the same occasion and on the Ministry's website - strengthens Austria's Central European position as well as the country's image in 
Western Europe. As Frölich-Steffen concludes in her study, in the government's view, admission to the EU defined Austria as a part of Western Europe, finally "healing the scars of the Second World War" (Frölich-Steffen 210).

Concerning the history of the twentieth century, another key development regarding the country's image and self-awareness can be noted. From the very beginning of Austria's path to the Second Republic, the year 1945 has been traditionally named "Stunde null" (hour zero), seen as the moment that brought upon Austria "ten years of occupation" (the liberation from the Nazis by the allied troops). Related to this, the choice of 26 October as Austria's national holiday was not understood as being based on "the neutrality pact signed that day" (which is the official explanation), but - as it is understood in almost every Austrian's consciousness - on the fact that on this day, "the last foreign soldier left the country" (i.e. "of the allied troops" which are normally imagined as Russian). It was the so-called "Waldheim scandal" in 1986 and the socalled "Gedenkjahr" (year of commemoration) in 1988 that initiated a process of reconsidering the clichés adopted in that area (keyword: Austria as the "first victim of the Nazis"). In 1991, Chancellor Franz Vranitzky apologized for the crimes committed by Austrians during the Third Reich, and since then measures have been taken to compensate the victims of the Nazi terror, neglected for far too long, and Aryanized property has been restituted - even if this has so far proceeded with hesitation and not without challenge. This process can be understood as an indication that the traditional construction of history currently seems, if not outdated, then at least to a certain degree challengeable, and that to reflect on Austria's role during the Third Reich now obviously constitutes to a certain extent a precondition for demonstrating Austria's readiness to (re)enter the European community, understood in terms of Western Europe. 


\section{WIE WIR UNS SEHEN:}
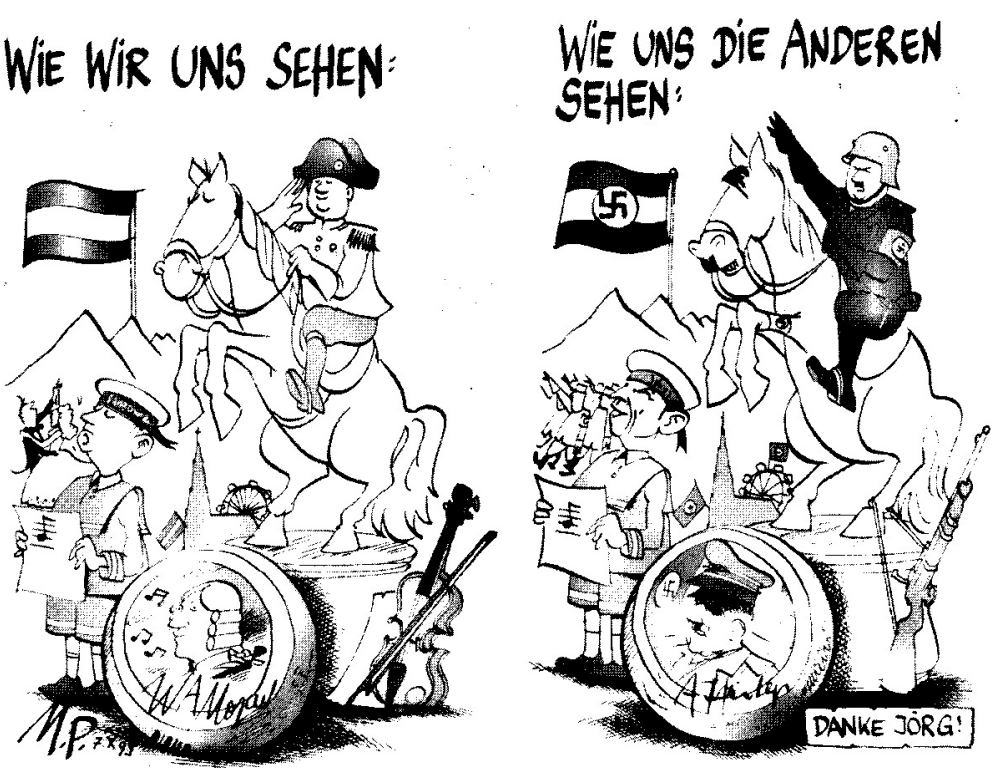

\section{Zweierlei Unsinn}

Illustration 2

Reflecting on National Socialist Austria adds to the parameters of how Austria's European awareness is being constructed in the current narrative of "how it all developed." The next step is to analyze last year's commemorative activities and events by asking which foci, which approaches and images concerning the Musikland topos are reflected in statements as well as in the music involved. The question is: if a new twist has been added to the old cliché, have there been considerable changes, and if so - what and where are they? Is there a difference between public and private, political and (music)cultural? 


\section{1) Events of official representation and of edification}

These are events not meant to attract as large a number of people as possible by entertainment, but which rather target an educated audience and are meant to impress and to recall elements of cultural memory by mass media coverage of the corresponding ceremonies (which are open to only a limited, select audience).

On 27 April 2005, a ceremony was held in the Hofburg to celebrate the $60^{\text {th }}$ anniversary of the Second Republic. It featured the presentation of a documentary (by Hugo Portisch), speeches by the former EU commissioner for agriculture, by Chancellor Schüssel, by the chair of the council of provincial governors Hans Niessl, and by actress Judith Holzmeister, who in 1955, at the re-opening of the Burgtheater, had performed in Grillparzer's above-mentioned King Ottokar, His Rise and Fall, and who had been "the voice" in a famous documentary by Ernst Haeussermann, Die Stimme Österreichs (the voice of Austria) at that time. In between the spoken words, pieces of music performed by a string quartet provided an element of increased ceremoniousness in a building where normally only spoken words are heard. The composers whose works were performed were, apart from Mozart (the Republic's Patron Saint was represented by the first movement of his Quartet B major K 458), Anton von Webern (Rondo for String Quartet (1906)) and Ernst Krenek (Quartet V op. 65/1). It is obvious that what counts in this case is not popularity or easy listening but cultural representation. Anton von Webern is the most complicated and avant-garde of Schönberg's students, who was shot in an accident by a US soldier during the last days of World War II, and whose music was the basis for much of the avant-garde in 1950s Germany and Austria (including Peter Kubelka's so-called "structural films"). Ernst Krenek, on the other hand, is not only the composer of Jonny spielt auf, an opera persecuted in the 1930s by the National Socialists as "degenerate" because of some chords in the jazz idiom and its Afro-American title hero, but he also represents a conservative Austrian patriotism popular during the Austro-fascist corporative state. He became respected (after a period during which his "Americanness" had been heavily criticized) as the contemporary composer in Austria (among others, he received the City of Vienna's Award in 1955 and the Major Austrian State Prize in 1963). To put it succinctly, the Hofburg celebration program intends to demonstrate a 
broad approach to the musical heritage and is nevertheless rather traditional in the historical images of music in Austria it presents. Apart from the above-mentioned concert in the State Opera on the Austrian national holiday itself, the Parliament's visitors' center was opened on the evening before, and a gala at the Spanish Riding School took place as well.

While the State Opera and Burgtheater commemorated their reopenings with corresponding celebrations invoking moments of commemoration with selected texts and history recalled in speeches, the Vienna Volksoper (which, in contrast to the two other buildings, was not damaged during WWII) not only staged an evening of looking back at 50 years of repertory on 11 May 2005, but it was also the scene of a special Austrian première on the evening of the national holiday, which involved examining its National Socialist participation in the context of an Austrian representative commemoration, namely the opera Sophie's Choice by Nicholas Maw (cf. en.wikipedia.org/wiki/Nicholas_Maw) with star soprano Angelika Kirchschlager (who had also performed the title role in the 2002 London première). The piece is based on a 1979 novel by William Styron, which was turned into the 1982 film starring Meryl Streep (cf. www.imdb.com/title/tt0084707) and is the moving story of a sadistically grounded fatal attraction against the backdrop of the Holocaust, which has been physically but not mentally survived. Its German-language version was translated by Nobel prize-winning author István Kertész, himself known for novels based on autobiographical Holocaust experiences.

Culture as a means of including the painful in a series of solemn celebrations or commemorations - this can also be defined as the basis for an educational event that seems, at first glance, a bit odd but is actually very characteristic of the current structures of Austria's culture of commemoration. The International Research Centre for Culture (IFK), together with the Sigmund Freud foundation, scheduled a series of discussions under the motto "conflicts of remembering," with the aim of raising "questions of commemorating the victims of the National Socialist machinery of extermination in a comparative context" (cf. www.freud-museum.at/erinnerungen/29-november_de.html). Event topics covered politically and ethically serious academic questions, ranging from "Do States Need Memory?" to "Remembrance and Violence in the Former Yugoslavia." The finale on 29 November 2005 represented a desire to build up to a "moving moment" in the form of an event at the City of Vienna's Music Collection, where "bread and wine" 
were served and literature readings (by prominent radio voice, musicologist, and author Otto Brusatti) and music were included. This may seem to diverge from the preceding events, but the mixture of serious discussion with culture and, above all, music is a well-known pattern, as is the demonstration of a politically correct way of dealing with history in cultural programming. The music added to this interpretation - Duo Dobrek-Bistro (cf. www.dobrek-bistro.com) performed the Belvedere Open Air (see below) with music that characteristically combines many kinds of popular styles, including not only jazz but also Balkan and Jewish folklore - may well be understood as communicating the message that Austria is a bridge-builder of styles, a mediator between southeastern Europe and the EU. To quote a definition ascribed to Krzysztof Dobrek himself:

Our salsa sounds gypsy-like, the tango Viennese, the jazz Yiddish, and the mussette has a Russian touch. Yes, and one could add that the musical provinces sound like the big wide world, and that the big wide world does not deny its cultural roots at Dobrek Bistro.

2) Events of (mass) entertainment

Entertainment understood as event-culture (Eventkultur) is a common part of all kinds of public representation and political promotion. Thus, when Austria for the first time held the chair of the EU council in 1998, a big party was organized in order to draw public attention to this event's importance and to promote Austria's European identity at the same time. 


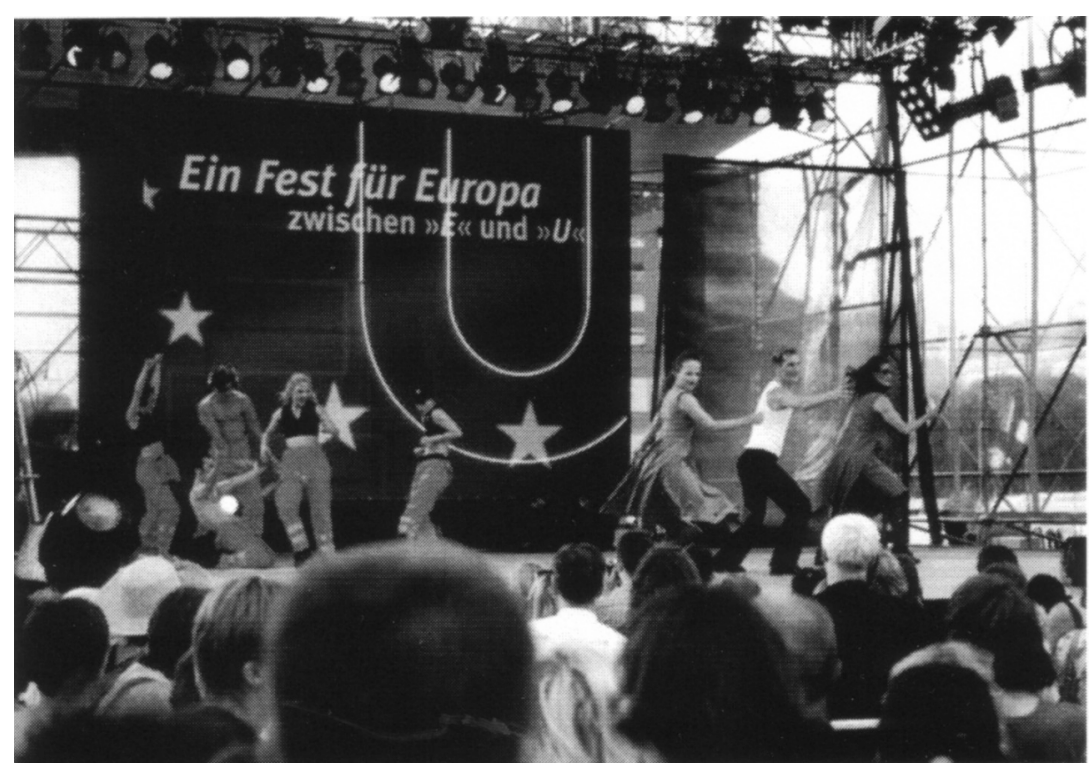

Illustration 3

The site was chosen with care: the Heldenplatz, one of Austria's most prominent and most contested lieux de mémoire (Stachel). The programmatic title "Journey between E and $\mathrm{U}$ " is not only a pun but is also telling for a music program that wants to both exploit music's qualities for identity production and attract a mass audience, which means it has to be musically popular and trendy. Described as an event bridging "traditional art and popular entertainment, Austria and Europe" (cf. www.wien.gv.at/archiv/eurat/veranst.htm; and I think it is telling that this formulation seems to identify Austria with the highbrow and Europe with popular culture), the selection of the program involved the Federal Chancellery and the Ministry of Foreign Affairs "consulting" the City of Vienna's Cultural Department, an indication of the event's highly official character and political importance.

A closer look at the program reveals familiar characteristics. The first part - "Youth for Europe" - targeted its audience with "performances of young Austrian bands," followed by a part called "Multitude Europe," during which actor Alfons Haider, in "a mix of relaxed small-talk and video-wall clips," demonstrated Austria's way into the EU: "an entertaining and exciting discussion of politics, spirit, history and vision. Contributions from member countries of the EU show the multitude of nations united." Most telling in the context of this 
analysis, however, is the following main attraction from $8 \mathrm{pm}$ to midnight (cf. the program www.wien.gv.at/archiv/eurat/veranst.htm).

Dedicated to "Austria for Europe," local artists "with international reputations" performed on two stages, "communicating between $\mathrm{E}$ and U." The "E," i.e. art music, was marked as Austrian by the usual suspects, i.e. Johann Strauß and W.A. Mozart (I could do a separate paper on the construction which elevates the dance musician Strauß to the parnassus of Austrian art music), while the U turned out to be celebrities of local popular culture, namely Falco (amadeus, amadeus) and the "Vienna Art Orchestra's conductor Matthias Ruegg." The first "Welcome to Europe" was represented by the choreography of Johann Strauß's Blue Danube Waltz, performed by the State Opera ballet and the Vienna Symphony Orchestra, and by "impressions on cello from Strauß to Falco," followed by Mozart's piano concerto K 466 (Vienna Symphony Orchestra/Rudolf Buchbinder) and by "From Mozart to Ruegg").

Striving to cover every musical taste possibly popular and to demonstrate musical trendiness at the same time, the following program sections were based: on folklore in its commercialized form ("Vom Krawatljodler bis zu den Holzhacker Buam - Volksmusikinstallation über den Dächern"); on religious as well as pop music kitsch combined again with Johann Strauß to create moments of special sentimentality to which the Vienna Choir Boys added (Thunder and Lightning and Ave Maria), Ave Maria and Here I Am by Sandra Pires and Erwin Kiennast; and on everything marked at any time for any reason as Austrian: from Arnold Schönberg (who has in the meantime become a fixture in the canon, as evidenced by the founding and the work of the so-called Arnold Schönberg Center Vienna, his Survivor from Warszaw probably standing for Austria's readiness to deal with its participation in Nazi terror while at the same time duly stressing the elements of exile and of being on the right side) to Austro-Pop (Fendrich, Danzer, Ambros) and the electronic music branded as the "Third Viennese School" (Kruder and Dorfmeister).

This apparently deliberate mix of high-brow and commercialized musical entertainment of all kinds is highly characteristic of all the programming for public events at which the Musikland is represented at a European level which clearly wish to stress Austria's up-to-date-ness. This is particularly remarkable because it signifies a considerable change. Already during the 1920s art music was no longer sufficient to represent the Musikland paradigm because it did not represent the 
cultural practice of the target group, but the forms of non-high-brow music included were locally coded (i.e. Viennese songs, Johann Strauß, operetta). This is no longer possible. Over the second half of the twentieth century, the repertory of everyday music changed in terms of identity markers: first, towards the international, as the global popular music of youth culture became a signifier of personal identity set apart from (adult) mainstream culture; and then again, as this young generation grew up (being now in their fifties and sixties). This implies that international popular music has actually shaped not only the taste but, above all, the cultural memory of most generations now actively participating in public life. Therefore, popular music styles have to be included in public events that wish to address as broad an audience as possible, styles that, at the same time, present a problem in representing national - in this case "Austrian" - identity. One way of dealing with this issue is obviously to rely on "Austrian" performers (Falco, Vienna Art Orchestra, etc); another is to rely on a mix of styles that leaves the part of local identification to the traditional repertory and the part of personal attachment, of "deep emotion," to pop. The problem with this approach is that, in such a construction, the pop repertory is constantly changing, which complicates or even prevents building a "canon" that might become an element of cultural memory. That seems to be difficult, something better left to the cultural museum.

Another example of events characterized by the same kind of programming are the Vienna Philharmonic's so-called "Concerts for Europe" and their promotion (not by the orchestra, but by a professional agency). The first of these - an open-air concert in front of Schönbrunn Palace - took place in 2004 and involved the Vienna Philharmonic. It is rumored to have been a special wish of Chancellor Schüssel himself, and the promotion alludes to the EU as a community of peace, a pattern we have already encountered:

The enlargement of the EU is a reason for joy: Europe is a continent of peace in which the countries are united in friendship. In our Europe, united again, it is important that we listen to each other, that we are sensitive to nuances, and that we strive for a harmonious unity within diversity. This idea shall reverberate in the Concert for Europe. (www.europa-konzert.at/konzert.htm of 26 May 2004)

The orchestra's chair, Clemens Hellsberg, referred to the equally clichéd idea of music as a universal language:

Music being the single language understood by all groups and nations and thus able to contribute to Europe's new unity. (ibid; cf. the significance of Haydn 
mentioned in this paper's introduction; cf.

www.europa-konzert.at/DATA/pressetext3.pdf

and

wienerphilharmoniker.waldner.biz/index.pl?language $=$ de\&id $=416 \&$ nextsite $=$ de tail_prod\&previous_kat=47).

The concert CD's promotion text speaks of a "musical people's movement" of 90,000 live listeners, and Hellsberg explains that the program is a demonstration of the fascinating multitude of European music achieved by selecting masterpieces by composers from both the old and the new members of the EU, emphasizing the hope that this continent has finally found peace.

The second Concert for Europe was held in June 2005, and the program (cf. www.europa-konzert.at/DE/Index.html) was explained as follows: the Strauß piece as "a musical greeting from Austria," Tchaikovsky's Overture 1812 as a commemoration of how "Europe was devastated 60 years ago" and a tribute to the four signing states of the treaty through Nimrod from Edward Elgar's Enigma Variations, the Carmen Overtures by George Bizet, the first piano concert by Pyotr Ilyich Tchaikovsky and two pieces by John Philip Sousa (Semper fidelis and Stars $\mathcal{E}$ Stripes Forever). The evening's top attraction was a piece of Romantic music's golden oldies performed by a rising star, the pianist Lang (who played the Tchaikovsky piece). The concert ended with Lang performing a medley of well-known melodies from operas and operettas as an encore - which is in its genre something literally unheard of in a traditional classical concert setting and thus clearly points to the massentertainment, high-pop, as it were, character of this open air concert, leading to the statement that the Concert for Europe represents "Austria's new musical calling card for the world."

And indeed, a third concert with this trademark was announced, which, although bearing the same name, would have been of a different nature by its mere setting, staging musical entertainment in a hall and not in the open: on Austria's national holiday, the Vienna Philharmonic with conductor Valery Gergiev intended to perform, in the State Opera, a program of Richard Wagner (Overtures from Lohengrin and Tannhäuser and the Ride of the Valkyrie), Tchaikovsky (from Nutcracker - Dance of the Reed Pipes and Trepak, the $2^{\text {nd }}$ mov. and $3^{\text {rd }}$ mov. from his $6^{\text {th }}$ Symphony, the so-called Pathétique), and, again, Johann Strauß (KaiserWalzer, Champagner Polka). This project was not realized (for reasons unknown to the author - perhaps business reasons, trademarks, copyright, etc). 
Instead, a so-called "Concert for Austria," listed on the orchestra's website, took place. The programming is again a mix of pieces marked as popular classics and/or as Austrian (cf. www.wienerphilharmoniker.at $/$ index.php?set_language $=$ de\&cccpage $=c$ oncerts). The only name requiring explanation in this program (as Mozart and Strauß are usual suspects and Beethoven not only another classical master but necessary on account of the soloist, who performed one of the composer's popular pieces) is Theodor Berger, an Austrian composer of a moderately modern style, who began working as a freelancer in 1939 and was supported by Herbert von Karajan after World War II.

Another event in this category is the Belvedere Open Air, a celebration in front of the eponymous palace. The rationale for this event was that it was the site at which, on 15 May 1955, the state treaty was signed, giving Austria full independence. This occasion was turned into a lieu de mémoire full of pathos, the image of which was constructed from coverage in contemporary movie theaters' newsreels (cf. Boisits/Uhl/Stachel). For the 50th anniversary of this moment, a state ceremony took place and was broadcast not only by the Austrian Television but also on video screens in the Belvedere Palace's park, where at the same time a festival was held, defined by the organizers as a total work of art intended to take "four generations celebrating an Austria we are proud of" on a "cultural journey," a celebration conceived of as a "crossroads between looking back and looking forward," bringing together on the same stage "artists from Austria, from Europe and from the treaties' signatory nations" (www.oesterreich2005.at/Desktop.DE/Österreich 2005. Jubiläen, Programme, Kalender pdf. p. 2; information from the program folder: oesterreich2005.at/Docs/2005/4/18/1505_folder.pdf) All told, 240 artists, 25 orchestras, ensembles and bands, 28 soloists and duos, 6 dancing companies, and a number of contemporary witnesses performed an 11 hour-long program, illustrating the chronology of Austrian postWWII history, starting with an overture "from the time of the Second World War to the signing of the state treaty," equally involving "art and artists from the signing nations" (such as the Bolshoi Don Kossaks, an homage to Edith Piaf, British ' $n$ ' Brass, and Melanie Holiday). The final part, devoted to the present ("Now!"), was intended as a "multicelebration of Austria": "Joe Zawinul meets Alegre Corrêa and Friends (with, among others, Sandra Pires, Roland Neuwirth, Krystof Dobrek, 
Aliosha Biz, Daisy Jopling, Wolfgang Muthspiel), followed by the "Ode to Joy" (the European anthem).

Not least but last, the Austrian National Army produced a festive calendar to celebrate its founding 50 years ago - a calendar, which not only lists the predictable international meeting of military bands (on 20 May 2005 in Salzburg), but which also contains the following entry, announcing an event special in both its nature and its location: on 23 July 2005, the newly renovated Rossauer barracks in Vienna were opened to the public for five open-air performances of Giuseppe Verdi's not-toopopular opera Attila, performed by a small company called Opernwerkstatt Wien ( $w w w$ w.opernwerkstatt.at) and financed by the Austrian Ministry of Defence (which has their offices in the barracks).

A conclusion beyond the results already mentioned does not seem warranted, but it is safe to conclude that, as history obviously marches along, so will the options for someone interested in meanings and contexts of culture to find new material for their curiosity.

\section{REFERENCES}

Boisits, Barbara, Peter Stachel, and Heidemarie Uhl. "Mythos Staatsvertrag - Mythos Musik", in: ÖMZ (Österreichische Musikzeitschrift) 4 (2005): 4-11.

Breuss, Susanne, Karin Liebhart, and Andreas Pribersky, eds. Inszenierungen. Vienna: Sonderzahl, 1995.

Frölich-Steffen, Susanne. Die österreichische Identität im Wandel. (Studien zur politischen Wirklichkeit 15). Vienna: Braumüller, 2003.

Knapp, Marion. Österreichs Kulturpolitik und das Bild der Kulturnation. Frankfurt/Berlin: Peter Lang, Europäischer Verlag der Wissenschaften, 2005.

Nußbaumer, Martina. Music City under Construction. "Musikstadt Wien" als Medium von Identitätspolitik 1860 - 1914, PhD Dissertation, Graz 2005.

Stachel, Peter. Mythos Heldenplatz. Vienna: Pichler, 2002.

Szabó-Knotik, Cornelia. "Mythos Musik in Österreich: die Zweite Republik." Memoria Austriae I. Menschen, Mythen, Zeiten. Eds. Emil Brix, Ernst Bruckmüller and Hannes Stekl. Vienna: Verlag für Geschichte und Politik, 2004. 243-70.

Szabó-Knotik, Cornelia. "Selbstinszenierung und Handelsbilanz. Die (Re)Konstruktion Österreichs nach 1945 mittels Musik." Musik-Wissenschaft an ihren Grenzen. Manfred Angerer zum 50. Geburtstag. Eds. Dominik Schweiger, Michael Staudinger, and Nikolaus Urbanek. Frankfurt/Berlin: Peter Lang, Europäischer Verlag der Wissenschaften, 2004. 355-82.

\section{L L USTR A T IO NS}

\#1 Identity05-2.jpg from: Österreich 2005. Ein Gedankenjahr pdf. on www.oesterreich2005.at p.15

\# 2: Identity05.jpg from: Profil 08/05

\# 3: Identity05festeu.jpg: from same source as \# 1, p. 16 